\title{
Cutting characteristics of dental diamond burs made with CVD technology
}

\section{Características de corte de pontas odontológicas diamantadas obtidas pela tecnologia CVD}

\author{
Luciana Monti Lima* \\ Cristiane Motisuki** \\ Lourdes dos Santos-Pinto*** \\ Ary dos Santos-Pinto*** \\ Evaldo Jose Corat****
}

\begin{abstract}
The aim of this study was to determine the cutting ability of chemical vapor deposition (CVD) diamond burs coupled to an ultrasonic dental unit handpiece for minimally invasive cavity preparation. One standard cavity was prepared on the mesial and distal surfaces of 40 extracted human third molars either with cylindrical or with spherical CVD burs. The cutting ability was compared regarding type of substrate (enamel and dentin) and direction of handpiece motion. The morphological characteristics, width and depth of the cavities were analyzed and measured using scanning electron micrographs. Statistical analysis using the Kruskal-Wallis test $(p<0.05)$ revealed that the width and depth of the cavities were significantly greater when they were prepared on dentin. Wider cavities were prepared when the cylindrical CVD bur was used, and deeper cavities resulted from preparation with the spherical CVD bur. The direction of handpiece motion did not influence the size of the cavities, and the CVD burs produced precise and conservative cutting.
\end{abstract}

DESCRIPTORS: Dental cavity preparation; Ultrasonography; Diamond; Dentistry, Operative.

RESUMO: O objetivo deste estudo foi determinar a habilidade de corte das pontas de diamante obtidas pelo processo de deposição química a vapor (CVD) associadas ao aparelho de ultra-som no preparo cavitário minimamente invasivo. Uma cavidade padronizada foi preparada nas faces mesial e distal de 40 terceiros molares, utilizando-se pontas de diamante CVD cilindrica e esférica. A habilidade de corte foi comparada quanto ao tipo de substrato (esmalte e dentina) e quanto à direção do movimento realizado com a ponta. As características morfológicas, a largura e profundidade das cavidades foram analisadas e medidas em microscopia eletrônica de varredura. A análise estatística pelo teste de Kruskal-Wallis $(\mathrm{p}<0,05)$ revelou que a largura e profundidade das cavidades foram significativamente maiores em dentina. Cavidades mais largas foram obtidas quando se utilizou a ponta de diamante CVD cilíndrica, e mais profundas quando a ponta esférica foi empregada. A direção do movimento da ponta não influenciou o tamanho das cavidades, sendo os cortes produzidos pelas pontas de diamante CVD precisos e conservadores.

DESCRITORES: Preparo de cavidade dentária; Ultrasonografia; Diamante; Dentística Operatória.

\section{INTRODUCTION}

The concepts of adhesive dentistry are generally applied to cavities prepared with the traditional handpiece and dental bur. However, alternative devices for dental cutting have been suggested for cavity preparation and finishing in an attempt to further preserve tooth structure and take advantages of new bonding systems.

Recently, the technology for diamond growth by chemical vapor deposition (CVD) has been used for the fabrication of new dental burs with continuous diamond films (CVDentUS ${ }^{\circledR}$ - Clorovale Diamantes, São Paulo, Brazil). The direct CVD diamond deposition on molybdenum tips allows a fabrication process that exhibits high adhesion characteristics of the diamond coating. The new diamond coated burs obtained by this process are adaptable to the handpiece of any ultrasonic instrument commonly used in dental

\footnotetext{
* MD, Graduate Student; **DDS, Graduate Student; ***PhDs, Associate Professors - Department of Pediatric Dentistry, School of Dentistry of Araraquara, São Paulo State University.

**** PhD, Physicist Researcher, National Institute for Space Research (INPE).
} 
Lima LM, Motisuki C, Santos-Pinto L, Santos-Pinto A, Corat EJ. Cutting characteristics of dental diamond burs made with CVD technology. Braz Oral Res 2006;20(2):155-61.

offices for calculus removal. According to Borges et al. ${ }^{1}$ (1999), the new dental diamond bur consists of a continuous film of diamond without a metallic binder between crystals, preventing the contamination of the tooth by metal ions usually present in the binder matrix of conventional burs. The CVD burs are also highly resistant to cutting and demonstrate efficient cutting ability and longevity.

Some researchers demonstrated that CVD diamond burs used for cavity preparation present similar or better performances than the conventional diamond bur in microleakage ${ }^{3,10}$ and bond strength tests ${ }^{8}$, but information on the characteristics of the cavity generated in enamel or dentin with CVD burs so far is not available in the literature. The purpose of this in vitro study was to analyze the morphological characteristics of the cavities prepared with CVD burs and to evaluate whether different CVD bur shapes and directions of the ultrasonic handpiece motion would affect the size of cavity preparation on enamel and dentin. The size of cavity preparation was defined, in this study, as the measurement of the width and depth of the cavities. The null hypotheses to be tested are: there is no difference in cavity sizes prepared with CVD burs coupled to an ultrasonic device regarding type of dental tissue, bur shape and direction of the ultrasonic motion.

\section{MATERIALS AND METHODS}

The cutting characteristics of two CVD burs (UCP1215 and UEE1010, CVDentUS ${ }^{\circledR}$ - Clorovale Diamantes, São Paulo, Brazil) coupled to an ultrasonic dental unit handpiece (Prof I AS Ceramic Dabi Atlante ${ }^{\circledR}$, Ribeirão Preto, Brazil) were tested using 40 extracted human non-carious third molars. The teeth were gathered with the patients' informed consent (Protocol $n^{\circ} 20 / 02$ ), approved by the institutional ethics committee. The teeth were obtained from young adults (ages ranging from 17 to 23 years). After extraction the teeth were debrided with a periodontal curette, cleaned and stored in $1 \%$ thymol solution at room temperature for up to 2 months.

Each tooth had its root removed and the coronal portion was sectioned longitudinally following the buccolingual plane. The sectioned teeth were set in blocks of methacrylate resin so that either the mesial or distal enamel surface or the internal dentin surfaces were exposed. The specimens were randomly assigned to eight different groups ( $\mathrm{n}=10)$, as described in Table 1 .

One standard cavity was prepared in each specimen. Operation of the ultrasonic handpiece was controlled using an experimental electro-mechanical apparatus that held both the specimen and the handpiece. The handpiece was mounted on an adjustable holder and the CVD bur was aligned to touch the tooth surface. This device standardizes cavity preparation by controlling the distance traveled $(3.5 \mathrm{~mm})$, the speed $(5.3 \mathrm{~mm} /$ s) of the handpiece, the load $(0.12 \mathrm{~N})$ of the bur against the specimen and the preparation time (30 s). The ultrasonic unit was operated at $26 \mathrm{kHz}$ oscillation frequency and an acoustical power of approximately $24 \mathrm{~W}$. For each test group, all ten specimens were tested sequentially using the designated bur shape and direction of the handpiece working movement (Figure 1).

The test surfaces were sectioned, dividing the cavity in two halves. The sectioned specimens were examined by SEM with $50 \mathrm{X}$ magnification (JSM - 5600LV, JEOL-USA, Inc., Peabody, MA, USA) to determine the width and the depth of the cavities. A technique modified from cephalometric analyses $^{12}$ was applied to measure the size of the

TABLE 1 - Experimental design of the study.

\begin{tabular}{|c|c|c|c|c|}
\hline Time & Substrate & Type of bur & Motion direction & Groups $(\mathrm{n}=10)$ \\
\hline \multirow{8}{*}{$30 \mathrm{~s}$} & \multirow{4}{*}{ Enamel } & \multirow{2}{*}{ Cylindrical } & Parallel & 1 \\
\hline & & & Perpendicular & 2 \\
\hline & & \multirow{2}{*}{ Spherical } & Parallel & 3 \\
\hline & & & Perpendicular & 4 \\
\hline & \multirow{4}{*}{ Dentin } & \multirow{2}{*}{ Cylindrical } & Parallel & 5 \\
\hline & & & Perpendicular & 6 \\
\hline & & \multirow{2}{*}{ Spherical } & Parallel & 7 \\
\hline & & & Perpendicular & 8 \\
\hline
\end{tabular}


Lima LM, Motisuki C, Santos-Pinto L, Santos-Pinto A, Corat EJ. Cutting characteristics of dental diamond burs made with CVD technology. Braz Oral Res 2006;20(2):155-61.

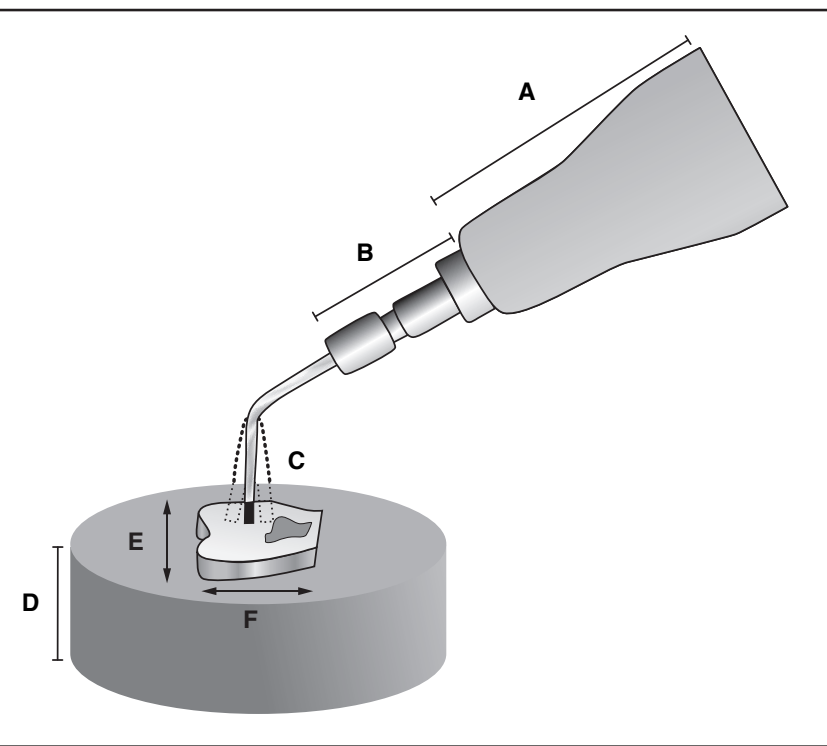

FIGURE 1 - Ultrasonic handpiece $(\mathbf{A})$; specific connector (B); direction of the bur oscillation (C); specimen in the blocks of methacrylate resin (D); ultrasonic handpiece working motion: perpendicular (E) or parallel to the direction of the bur oscillation $(\mathbf{F})$.

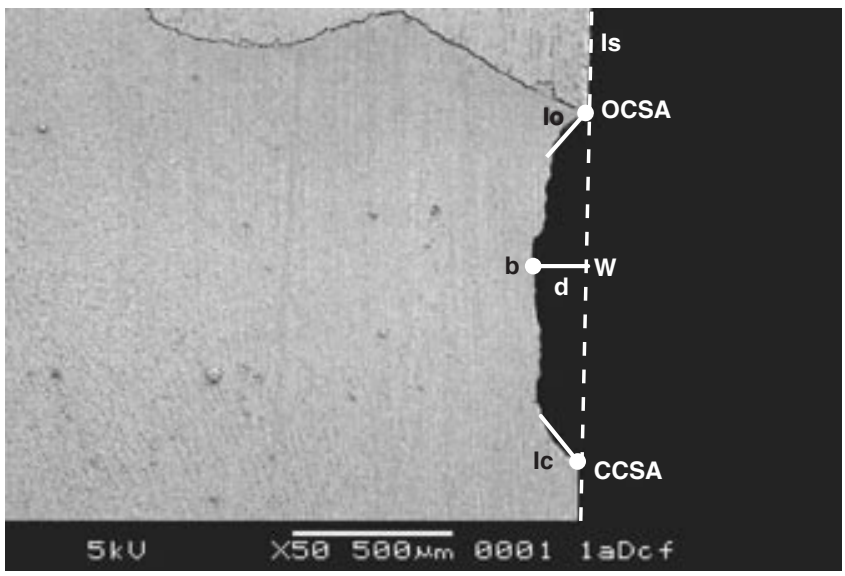

FIGURE 2 - Cross section of cavity prepared using a CVD bur showing the points, the traced lines and the measurements made using the digitizing program. OCSA: occlusal cavosurface angle; CCSA: cervical cavosurface angle; Is: approximately the original surface of the uncut enamel or dentin; lo: internal wall of the cavity from the occlusal side; Ic: internal wall of the cavity from the cervical side; w: width of the cavity measured between OCSA and CCSA; d: depth of the cavity measured between point $\mathbf{b}$ and line ls.

TABLE 2 - Means and Standard Deviations (SD) of the width and depth of the cavities for each experimental condition.

\begin{tabular}{|c|c|c|c|c|c|c|c|}
\hline \multirow{2}{*}{ Substrate } & \multirow{2}{*}{ Type of bur } & \multirow{2}{*}{$\begin{array}{c}\text { Motion } \\
\text { direction }\end{array}$} & \multicolumn{2}{|c|}{ Width $(\mu \mathrm{m})$} & \multicolumn{2}{|c|}{ Depth $(\mu \mathrm{m})$} & \multirow{2}{*}{ Group } \\
\hline & & & Mean & $\mathrm{SD}$ & Mean & $\mathrm{SD}$ & \\
\hline \multirow{4}{*}{ Enamel } & \multirow{2}{*}{ Cylindrical } & Parallel & 856.94 & 121.50 & 74.75 & 31.46 & 1 \\
\hline & & Perpendicular & $1,037.34$ & 129.23 & 99.37 & 26.50 & 2 \\
\hline & \multirow{2}{*}{ Spherical } & Parallel & 768.41 & 87.01 & 131.36 & 29.11 & 3 \\
\hline & & Perpendicular & 762.35 & 74.07 & 135.54 & 28.97 & 4 \\
\hline \multirow{4}{*}{ Dentin } & \multirow{2}{*}{ Cylindrical } & Parallel & $1,161.26$ & 22.76 & 150.58 & 25.67 & 5 \\
\hline & & Perpendicular & $1,199.90$ & 41.97 & 181.60 & 36.03 & 6 \\
\hline & \multirow{2}{*}{ Spherical } & Parallel & 882.83 & 100.69 & 211.55 & 44.98 & 7 \\
\hline & & Perpendicular & 879.93 & 50.42 & 235.60 & 32.36 & 8 \\
\hline
\end{tabular}

cavities. Figure 2 shows how the landmarks were identified for the measurements. The points were digitized and the distances were calculated using Radiocef 4.0 (Radiocef Memory Ltda., Belo Horizonte, Brazil).

The width and depth $(\mu \mathrm{m})$ of the cavities were measured and mean values and standard deviations were calculated. Data were analyzed by means of a Kruskal-Wallis non-parametric method performed on the rank order data at a significance level of $\mathrm{p} \leq 0.05$, and the Rank Sum Difference Multiple Comparison test was used to identify any difference.

\section{RESULTS}

Means and standard deviations of the width and depth of the cavities for each of the experimental conditions are summarized in Table 2. Results of the Kruskal-Wallis test showed statistical significant differences among the groups. It was apparent that the width and depth of the cavities prepared on dentin were significantly larger than on enamel. Tables 3 and 4 show the results of the pair-wise comparison between groups. The cavities prepared with the spherical CVD bur were significantly deeper while wider cavities were prepared with the cylindri- 
Lima LM, Motisuki C, Santos-Pinto L, Santos-Pinto A, Corat EJ. Cutting characteristics of dental diamond burs made with CVD technology. Braz Oral Res 2006;20(2):155-61.

TABLE 3 - Summary of the statistical analyses: Comparison of type of bur shape.

\begin{tabular}{c|c|c|c|c}
\hline \hline \multirow{2}{*}{ Motion direction } & \multicolumn{2}{|c|}{ Width } & \multicolumn{2}{c}{ Depth } \\
\cline { 2 - 5 } & Enamel & Dentin & Enamel & Cylindrical versus Spherical \\
\cline { 2 - 5 } & Cylindrical versus Spherical & $\mathrm{s}$ & $\mathrm{s}$ \\
\hline Parallel & $\mathrm{ns}$ & $\mathrm{s}$ & $\mathrm{s}$ & $\mathrm{s}$ \\
\hline \hline
\end{tabular}

$\mathrm{s}=$ statistically significant; $\mathrm{ns}=$ not statistically significant.

TABLE 4 - Summary of the statistical analyses: Comparison of motion direction.

\begin{tabular}{|c|c|c|c|c|c|c|c|c|}
\hline Motion direction & \multicolumn{4}{|c|}{ Width } & \multicolumn{4}{|c|}{ Depth } \\
\hline \multirow{2}{*}{$\begin{array}{l}\text { Parallel versus } \\
\text { Perpendicular }\end{array}$} & \multicolumn{2}{|c|}{ Enamel } & \multicolumn{2}{|c|}{ Dentin } & \multicolumn{2}{|c|}{ Enamel } & \multicolumn{2}{|c|}{ Dentin } \\
\hline & Cylind. & Spher. & Cylind. & Spher. & Cylind. & Spher. & Cylind. & Spher. \\
\hline
\end{tabular}

$\mathrm{s}=$ statistically significant; $\mathrm{ns}=$ not statistically significant.
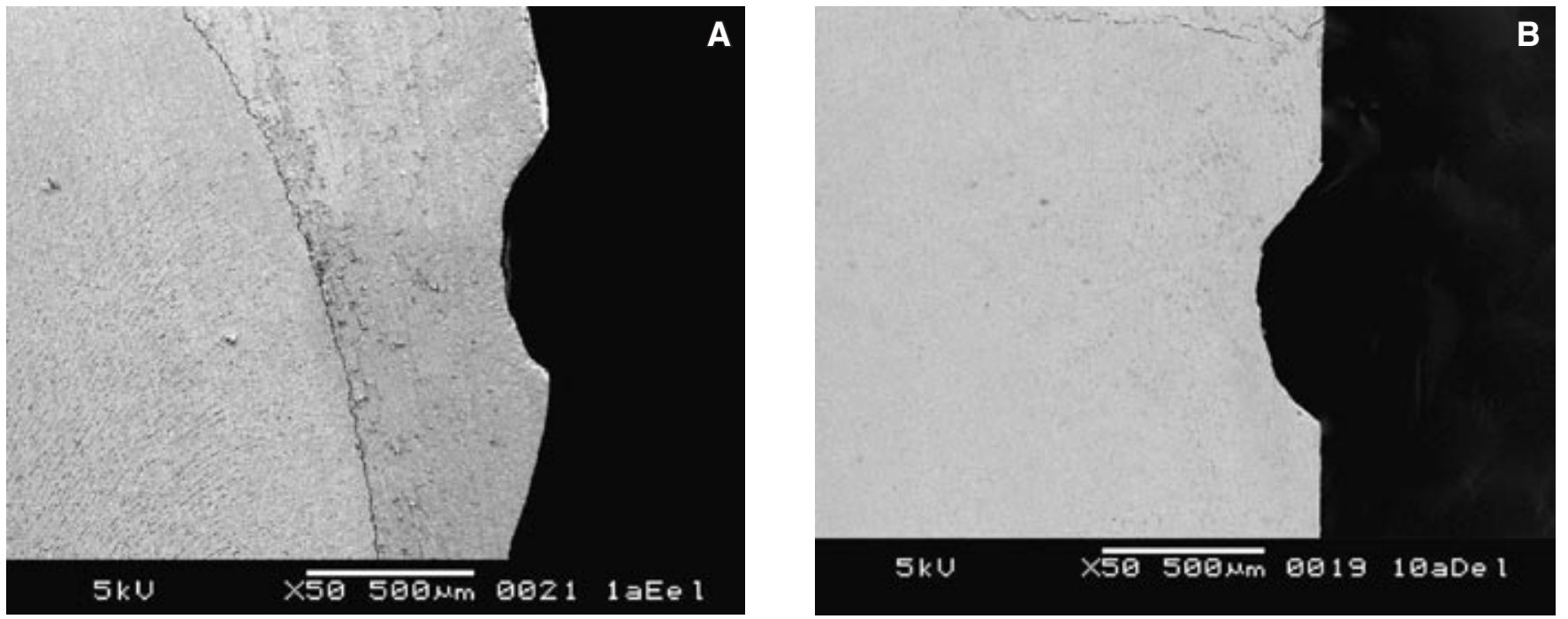

FIGURE 3 - Cavities prepared with spherical CVD bur in enamel (A) and dentin (B).

cal bur, even with the same width $(1.0 \mathrm{~mm})$ of the burs (Table 3). Differences in the cutting effectiveness as a function of the direction of the handpiece working movement were apparent only for enamel prepared with the cylindrical bur (Table 4).

Scanning electron micrographs revealed a cavity preparation without sharp internal angles (Figures 3 and 4). The morphological characteristics of the internal cavity wall were similar to the CVD bur surfaces (Figures 5 and 6).

\section{DISCUSSION}

One of the causes of failed tooth restorations is related to cavity design and preparation methods. Cavity design depends on the physical properties and requirements of the restorative material, the extent of the carious lesion, access to the cavity and available equipment and instrumentation.

With the advent of adhesive restorative materials and the subsequent development of minimal cavity design, several currently available instruments were introduced for removing caries and for cavity preparation. Since the design and surface finish of the cavity preparation produced by these new technologies differ from those produced using the traditional methods, a complete understanding of the CVD bur cavity preparation is needed so that clinicians using this methodology can select a 
Lima LM, Motisuki C, Santos-Pinto L, Santos-Pinto A, Corat EJ. Cutting characteristics of dental diamond burs made with CVD technology. Braz Oral Res 2006;20(2):155-61.
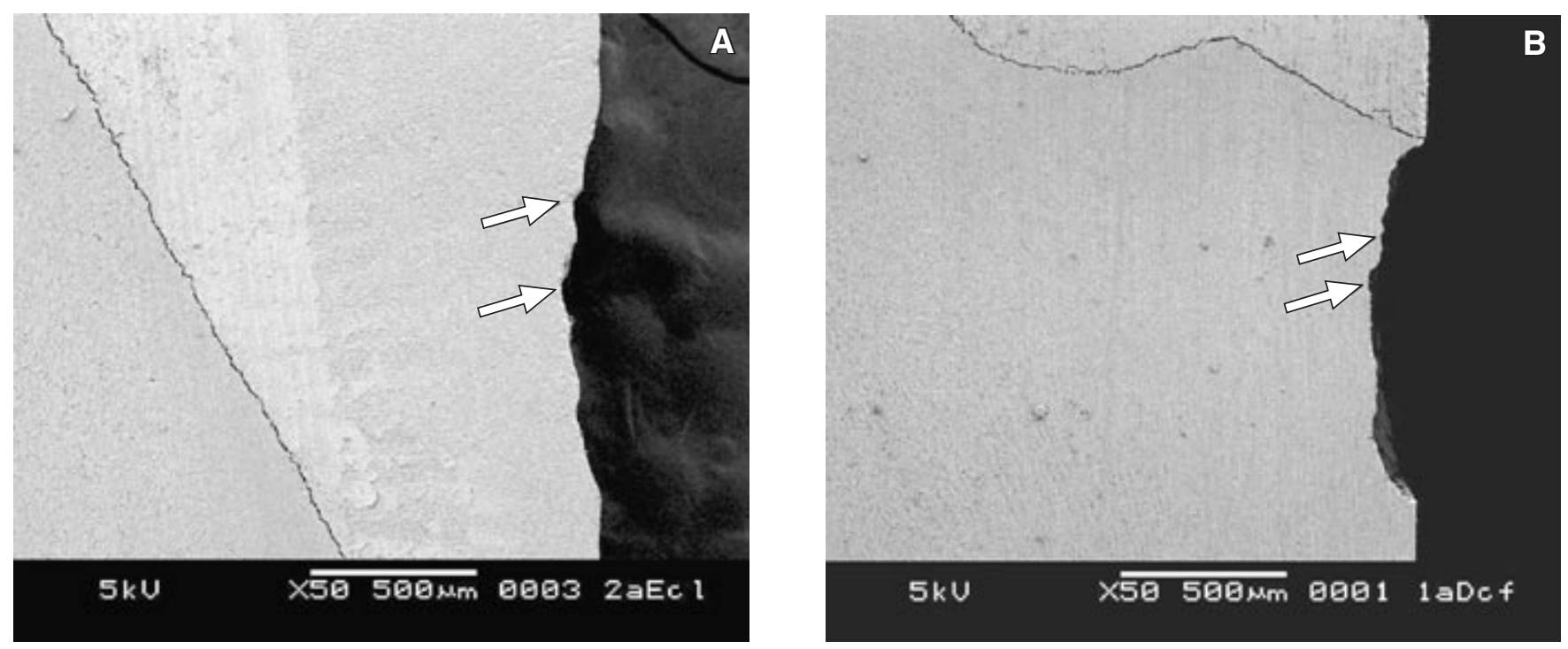

FIGURE 4 - Cavities prepared with cylindrical CVD bur in enamel (A) and dentin (B). Irregularities may have been made by different sizes of diamond (arrow).

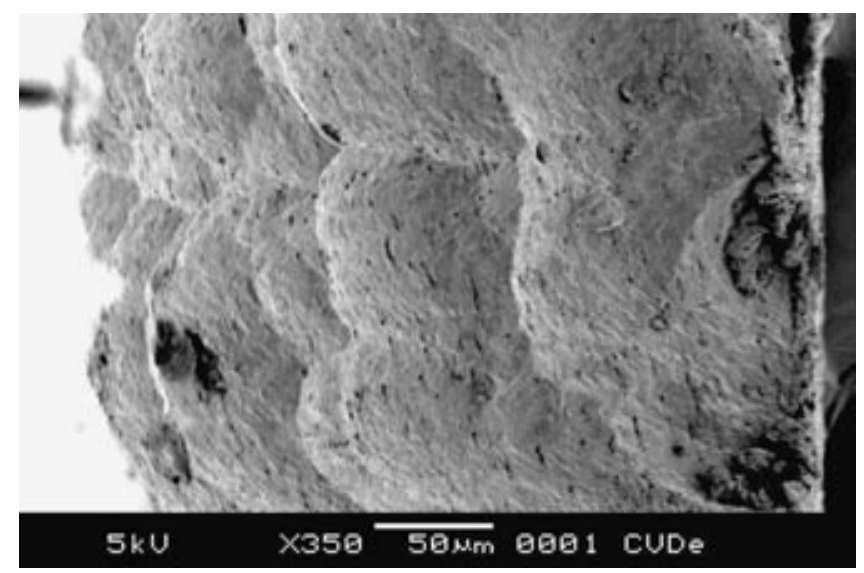

FIGURE 5 - Morphological characteristics of cavity wall.

specific bur to achieve expected outcomes.

SEM analysis demonstrated a distinct design in the prepared cavity produced by the different CVD bur shapes. Cavities made with the CVD spherical bur presented a "U" shape while those prepared with the cylindrical bur reminded a "[" symbol (Figures 3 and 4). Dietschi et al. ${ }^{2}$ (1994) reported that utilization of a U-shaped cavity is an effective method of treating primary caries lesions that, according to contemporary restorative concepts, are restored exclusively with composite resin. Figures 3 and 4 show that the shape of the bur plays an important role in the cavity appearance. However, the oscillating frequency of the bur and the direction of handpiece motion did not influence the cavity design. In all cavities, the margins of the preparation were well defined and no cracks on the cavity margin were observed in enamel or dentin. The internal walls had no sharp angles and presented some irregularities probably made by the different sizes of diamond crystals of the CVD burs (Figures 3 and 4). In cavities prepared with SonicSys (KaVo Dental GmbH \& Co. KG, Biberach, Germany), some irregularities observed on the cavity margins were attributed to the indentations of the diamond tip of the instrument ${ }^{13}$. Enamel cracking around the cavity preparation is commonly observed after laser irradiation ${ }^{5,11}$, application of high-speed diamond burs $\mathrm{s}^{4,7,15}$ and also with sonic instruments ${ }^{9,13}$.

Higher magnification of the cavity preparation revealed uniform roughness on the internal walls (Figure 5) similar to the diamond bur surface (Figure 6). In the cutting process, the "negative shape" of the bur surface was transferred to the tooth. This characteristic shows the accurate cutting produced by CVD burs, reproducing, on the tooth surface, the morphological shape of the CVD diamond crystal, while irregular lines on the cutting tooth surface are visible in cavities prepared with conventional diamond burs in a high speed device.

Data on relative cutting abilities of diamond burs were obtained as far back as 1955 . Hudson et $a l .{ }^{6}(1955)$ reported that diamond abrasive instruments used in high speed cavity preparation devices are more efficient when cutting tooth enamel, and Sockwell ${ }^{14}$ (1971) reported that diamond burs are effective for extra-coronal preparation, cusp 
Lima LM, Motisuki C, Santos-Pinto L, Santos-Pinto A, Corat EJ. Cutting characteristics of dental diamond burs made with CVD technology. Braz Oral Res 2006;20(2):155-61.
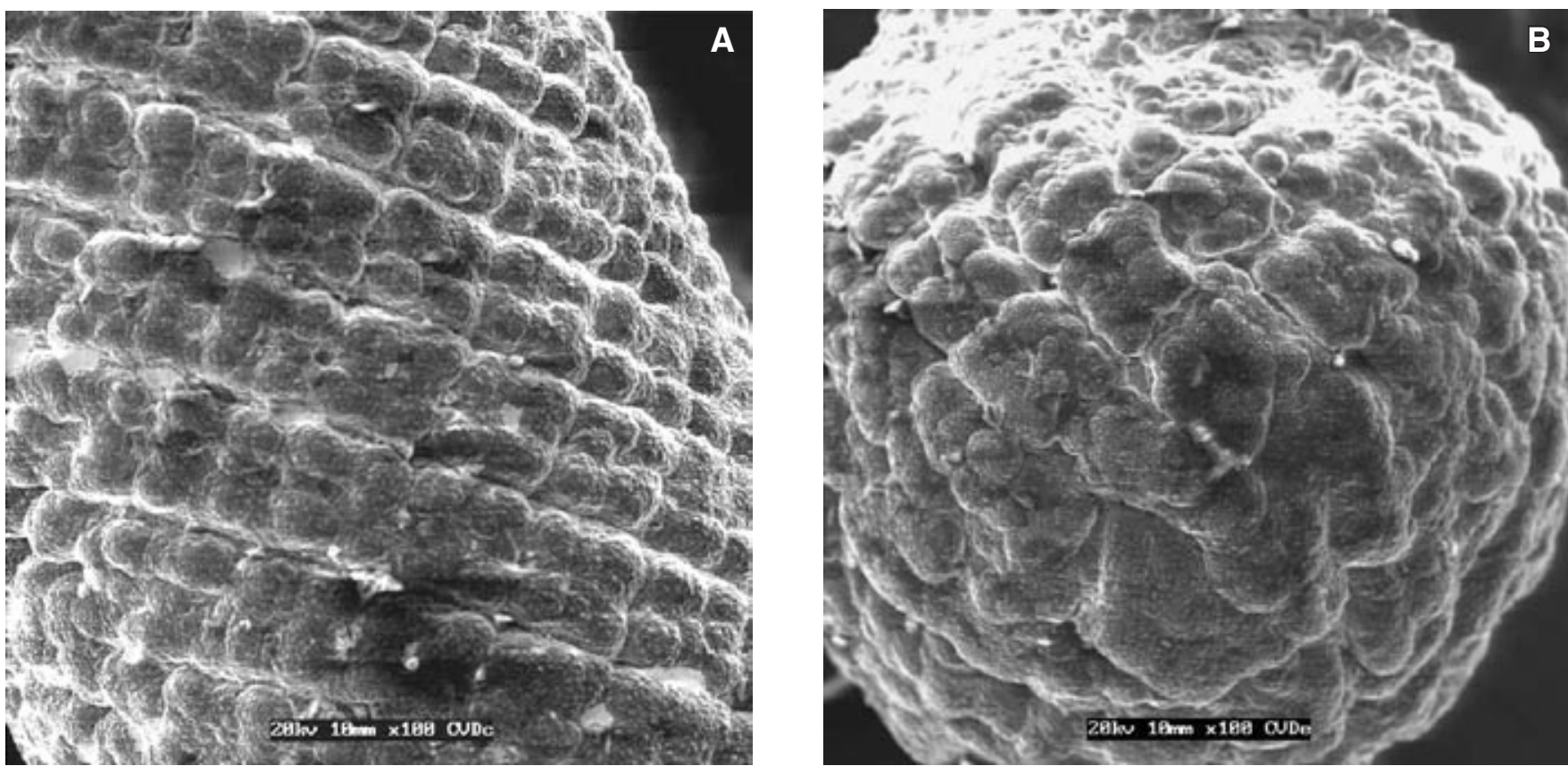

FIGURE 6 - Morphological characteristics of CVD burs' surface. Cylindrical shape (A) and Spherical shape (B).

reduction and beveling margins. However, in the present study, when the CVD bur was used on dentin, the cavities were wider and deeper.

The width of the cavities made with the spherical bur was approximately 35\% smaller than that made with the cylindrical bur. These findings may be explained by the fact that in the 30 seconds of application of the apparatus, the spherical bur did not penetrate into dentin enough to reach its greatest diameter $(1.0 \mathrm{~mm})$.

The direction of the handpiece motion did not alter the width of the cavities, except when the cylindrical CVD bur was used in cutting enamel perpendicular to the direction of the bur ultrasonic vibration. These results indicate that the width of the cavities obtained in this experimental condition was larger $(1,037.34 \mu \mathrm{m})$; however, its measurement was similar to the cylindrical bur diameter $(1.0 \mathrm{~mm})$. The fact that the width of the cavities is not different with the two directions of the working handpiece movement shows that the cutting action of the CVD bur is efficient when the handpiece movement is parallel or perpendicular to the direction of the bur oscillation. Once the bur has penetrated the tooth surface, moving it in any direction produced a similar cutting action. When using CVD burs in ultrasonic units, it is important for clinicians to be knowledgeable about the cutting efficiency with different bur shapes and movements to predict the cavity design.
The present results provided statistical evidence that the mean cavity depths observed in dentin were larger than those observed in enamel. The depth of the cavities made with the spherical CVD bur was approximately $40 \%$ greater than when the cylindrical bur was used. One of the probable explanations for this finding may be the smaller diameter of the spherical bur tip resulting in higher local pressure during the cutting procedure. The direction of the handpiece working movement did not alter the depth of the cavities.

The success of minimally invasive techniques is measured by the degree of preservation of sound dental hard tissue. The results of this study showed that this new cavity preparation method allows conservation of tooth structure. Since this technique does not require modification of a clinician's restorative technique or extensive training, the new dental diamond bur offers a promising perspective with regard to conservative cavity preparation.

\section{CONCLUSION}

- The cavities prepared in dentin were larger and deeper than in enamel, regardless of CVD bur shape and ultrasonic handpiece motion direction.

- The spherical CVD bur produced deeper cavity preparations, while cylindrical CVD bur produced larger cavity preparations. 
Lima LM, Motisuki C, Santos-Pinto L, Santos-Pinto A, Corat EJ. Cutting characteristics of dental diamond burs made with CVD technology. Braz Oral Res 2006;20(2):155-61.

- The direction of the ultrasonic handpiece motion, parallel or perpendicular to the direction of the bur ultrasonic vibration, produced cavities similar in width and depth, except for cavities in enamel made by the cylindrical CVD bur.
- The cavity patterns produced in this study indicated that the CVD burs allow the realization of conservative cavity preparation with well-defined walls and finishing margins.

\section{REFERENCES}

1. Borges CFM, Magne P, Pfender E, Heberlein J. Dental diamond burs made with a new technology. J Prosthet Dent 1999;82(1):73-9.

2. Dietschi D, Magne P, Holz J. Recent trends in esthetic restoration for posterior teeth. Quintessence Int 1994;25(10):659-77.

3. Diniz MB, Rodrigues JA, Chinelatti MA, Cordeiro RCL. Microinfiltração marginal em cavidades preparadas com pontas CVDentUS ${ }^{\circledR}$ e diamantadas convencionais. Cienc Odontol Bras 2005;8(1):75-81.

4. Feinman RA. High velocity air microabrasion for conservative tooth preparation: The principle and the clinical procedure. Pract Periodontics Aesthet Dent 1995;7(8):37-42.

5. Giusti JSM, Santos-Pinto L, Lizarelli RFZ, Bagnato VS. Ablation rates and morphological patterns of deciduous-tooth enamel after Er:YAG laser irradiation: An in vitro study. J Oral Laser Applications 2002;2(3):159-64.

6. Hudson DC, Hartley JL, Moore R, Sweeney WT. Factors influencing the cutting characteristics of rotating dental instruments. J Am Dent Assoc 1955;50(4):377-82.

7. Kasloff $Z$, Swartz ML, Phillips RW. An in vitro method for demonstrating the effects of various cutting instruments on tooth structure. J Prosthet Dent 1962;12(6):1166-75.

8. Lima LM, Motisuki C, Jacques P, Sanabe ME, Santos-Pinto L. Resistência de união de restaurações em resina compos- ta após preparo cavitário com instrumentos alternativos [resumo]. Braz Oral Res 2005;19(Suppl): 174.

9. Lussi A, Gygax M, Hotz P, Luthi D. A new method for finishing minicavities. Scanning Microsc 1988;2(3):1553-7.

10. Motisuki C, Lima LM, Cordeiro RCL, Santos-Pinto L. Efeito da técnica de preparo cavitário na microinfiltração de restaurações em resina composta [resumo]. Braz Oral Res 2005;19(Suppl): 175 .

11. Paghdiwala AF, Vaidyanathan TK, Paghdiwala MF. Evaluation of Erbium:YAG laser radiation of hard dental tissues: analysis of temperature changes, depth of cuts and structural effects. Scanning Microsc 1993;7(3):989-97.

12. Santos-Pinto L, Peruchi C, Marker VA, Cordeiro R. Effect of handpiece tip design on the cutting efficiency of an air abrasion system. Am J Dent 2001;14(6):397-401.

13. Setien VJ, Cobb DS, Denehy GE, Vargas MA. Cavity preparation devices: Effect on microleakage of class $\mathrm{V}$ resinbased composite restoration. Am J Dent 2001;14(3):15762.

14. Sockwell CL. Dental handpieces and rotary cutting instruments. Dent Clin North Am 1971;15(1):219-44.

15. Xu HH, Kelly JR, Jahanmir S, Thompson VP, Rekow ED. Enamel subsurface damage due to tooth preparation with diamonds. J Dent Res 1997;76(10):1698-706.

Received for publication on Jun 23, 2005

Sent for alterations on Nov 16, 2005

Accepted for publication on May 02, 2006 